\title{
MODIFICATION OF COMBINE HARVESTER HEADER FOR REAPING ALFALFA
}

\author{
ELYAMANI, A.E. ${ }^{1}$, S.K. GENAIDY ${ }^{1}$ and A.M. DREES ${ }^{2}$ \\ 1. Agric. Eng. Res, Inst., ARC, Dokki, Giza \\ 2. Fac. Agric. Assiout Univ., Egypt
}

(Manuscript received 9 January 2012)

\begin{abstract}
Experiments were conducted in West Nubaria by using combine harvester with modified header to fit reaping alfalfa to increase productivity and minimize losses. The effect of forward speed of $3.20,3.45,3.78$ and $4.32 \mathrm{~km} / \mathrm{h}$, cutting height of $3,5,8$ and $10 \mathrm{~cm}$, and cutter bar speed of $2.28,3.18$ and $3.78 \mathrm{~m} / \mathrm{s}$ were studied. Measured performance indicatoss include field capacity and efficiency, cutting efficiency, productivity, total losses, energy requirements, operational and criterion function costs of reaping alfalfa were evaluated. The results indicated that, maximum cutting efficiency of $98.6 \%$, minimum total losses of $3.28 \%$ and minimum criterion function costs of $91.54 \mathrm{LE} / \mathrm{fed}$ recorded with forward speed of $3.2 \mathrm{~km} / \mathrm{h}$, cutting height of $3 \mathrm{~cm}$ and cutter bar speed of $3.78 \mathrm{~m} / \mathrm{s}$, meanwhile maximum field efficiency was $90 \%$ recorded with previous condition as if cutting height was $10 \mathrm{~cm}$. Also, maximum field capacity of $3.72 \mathrm{fed} / \mathrm{h}$, while maximum productivity of $10.89 \mathrm{ton} / \mathrm{h}$, energy requirements of $35.39 \mathrm{~kW} . \mathrm{h} / \mathrm{fed}$, and harvesting operational costs of $53.4 \mathrm{LE} /$ fed recorded with forward speed of $4.32 \mathrm{~km} / \mathrm{h}$, cutting height of $10 \mathrm{~cm}$ and cutter bar speed of $3.78 \mathrm{~m} / \mathrm{s}$.
\end{abstract}

\section{INTRODUCTION}

Alfalfa is undergoing a cultural revolution more fodder crops cultivated worldwide importance as it is described as a fodder plant with high nutritional value for all types of animals, both dairy or beef that has many benefits and are summarized as install nitrogen atmosphere which would benefit other crops that grow beyond where approximately 80-100 kilograms of nitrogen from the air could be added to the soil per feddan per year, improve the properties of the soil by the add of organic matter and whole food contains all the food for the animals, milk and beef. Koegel et. al. (1985) measured mechanical losses of alfalfa for various harvesting processes by collecting them from plastic strips which were laid down concurrently with mowing-conditioning. Three types of mower-conditioners and three types of balers were compared. Total losses ranged from $6.1 \%$ to $27.1 \%$ of total dry matter (DR). Rotz et. al. (1987) showed that DM losses (which often exceeded 20\%) and quality changes were not affected by chemical or mechanical conditioning. A system that allows baling alfalfa hay at moisture high enough to decrease leaf loss without 
quality deterioration, characterized by excessive heating and mold damage, should improve its nutritive value. Rotz and Abrams(1988) told that dry matter loss and change in quality were monitored from standing alfalfa through hay storage. Field curing loss consisted primarily of constituents other than fiber and protein and averaged $3.2 \%$ for hay dried without rain damage and $11.2 \%$ for hay with rain damage. Protein became less soluble during field curing and a small loss of protein occurred with rain damage. Raking a wide swath into a windrow caused the greatest machine loss, this loss was inversely related to crop yield. The portion of the yield lost was $3.5 \%$ for raking, $0.8 \%$ for windrow turning, $1.8 \%$ for the baler pickup and $1.1 \%$ from the baler chamber. Machine losses were similar across all quality constituents so the quality of harvested hay was not affected much by the loss. Storage loss of dry matter averaged $4.2 \%$ for dry hay (11 to $20 \%$ moisture), $7.9 \%$ for 20 to $25 \%$ moisture hay and $10.9 \%$ for hay of 25 to $34 \%$ moisture. This loss was predominantly constituents other than fiber (nonstructural carbo- hydrate and protein). Carbohydrate loss was proportional to the moisture content of the hay entering storage while protein loss appeared independent of hay moisture. Buckmaster et. al. (1990) models of alfalfa losses through harvest, storage and feeding were incorporated into DAFOSYM, a model of the dairy forage system. The value of individual and combined losses were simulated for a 100-cow dairy farm located in East Lansing, Michigan. The value of the losses reflected the impacts of losses on the quantity and nutritive quality of alfalfa available for animal consumption. With a moderate milk production level $(8000 \mathrm{~kg} / \mathrm{cow}-\mathrm{yr})$, the most costly losses occurred during silage and hay storage and hay raking, mowing-conditioning and respiration losses were least costly. Sensitivity of loss value to several farm, animal and economic parameters is discussed. Buckmaster and heinrich (1993) stated that second- and third-cutting alfalfa hay was baled at moisture contents ranging from 11 to $38 \%$. Treatments included control, buffered propionic acid applied at 0.2 or $0.3 \%$ of wet weight, and propionic acid applied at 0.5 or $1.0 \%$ of wet weight. Effects of moisture content at baling on harvest losses, storage losses, and pre- and post-storage quality were determined. Quality into storage was not better for high moisture hay, quality after storage indicated benefits of baling lower moisture hay. Propionic acid reduced storage dry matter loss in hay with higher moisture levels. Sheaffer et. al. (2000) reported decreased crude protein (CP) and increased fiber content as well as changes in leaf/stem ratio alfalfa forage harvested at advancing maturity stages. Concentration in alfalfa have included increased leaflet Alfalfa harvested at mid bud had greater leaf yield than stem yield, while at early flower, leaf and stem yields were nearly the same. At late flower, the stem portion of the forage out yielded the leaves. Joann et. al. (2003) stated that, 
Alfalfa leaf and stem proportions influence its value as a livestock feed and as a biomass energy crop. For livestock feeding, harvest at bud to early flower is recommended to provide forage with high to medium nutrient concentration. Yiljep and Mohammed (2005) and Shaw and Tabil (2007), reported that the physical properties of the cellular material are importances in cutting, compression, tension, bending, density and friction. Nazari Galedar et. al. (2008) indicated that an increase in moisture content of stalk led to a decrease in the bending stress, young's modulus where this change led to an increase in the shearing stress and the shearing energy. The objectives of the study were:

1- Examination new development combine harvester header to suit reaping alfalfa crop,

2- Studying the effect of engineering parameters of machine on alfalfa stalks to estimate the optimum condition for operation, also.

3- Estimation energy required and operating cost essential for operation.

\section{MATERIALS AND METHODS}

The main experiments were carried out in west Nubaria region at season 2011 on an experimental area of about five feddans of Alfalfa crop variety Nubaria1. Alfalfa still harvested manually using tools such as sickle or mower. Combine harvest for limited duration around the year for harvesting seed crops. The combine harvest wheat, maize and rice. Therefore, the idea of this research is to modify the machine header to be able to harvest green fodder crop such as alfalfa grown in desert land and produce 8 cuts/year. Therefore the operation hours per year increased to decrease fixed costs.

\section{The used combine harvester after modification}

Italian made combine harvester model FIAT AGRE was used in this study. Table1 present the specifications and components which also shown in Fig 1, the machine has a header consists of crop lifter, front reel, single cutterbar knife, main table auger, feed rake, feeder housing and left over combine parts used for moving only. 
Table 1. Specifications of used grain combine harvester

\begin{tabular}{|c|c|c|}
\hline No. & Item & Value \\
\hline 1 & Model & FIAT AGRE \\
\hline 2 & Made & Italy \\
\hline 3 & Cutting width, $\mathrm{mm}$ & 4200 \\
\hline 4 & $\mathrm{LX} \mathrm{W} \times \mathrm{H}, \mathrm{mm}$ & $6560 \times 4200 \times 4650$ \\
\hline 5 & Capacity of grain tank, kg & 3000 \\
\hline 6 & Engine power, $\mathrm{kW}$ & 88.23 \\
\hline 7 & Total weight, $\mathrm{kg}$ & 2280 \\
\hline 8 & Reel diameter, $\mathrm{mm}$ & 1150 \\
\hline 9 & Cutter stroke, $\mathrm{mm}$ & 76.2 \\
\hline 10 & Reel type & Eccentric teeth type \\
\hline 11 & Reel rod number & 5 \\
\hline
\end{tabular}

\section{The general modified parts in combine harvester header}

The general modified parts carried out on the modified combine harvester header are shown in Fig. 2 and presented as follows:

1 - Replace the knife cut from a single cutter bar to double cutter bar blades to increase the effectiveness of tender pieces of sticks

2- Installation of a rubber section on the reel spring tine tube to strengthen the fingers to move the crop due to the high weight of the fresh crop named reel beams.

3 - To rig feeding auger for work totals of the feeding fingers provide with coupler in the driving segment devoted to the payment of the crop to lift legs named feeding fingers beams. That is set to conclude the feeding fingers to be less than what could be the bottom of the auger.

4 - Removing conveyer chain and making the lower side of the outer cover for this conveyer as output opening gate .

5 -Marking backward side of feeder housing working as output opening gate under conveyer used for going out reaping crop to allow the fall crop on the ground directly.

6 - Covering the front machine work tires to prevent the fall or rush the crop harvested from falling into the bottom of the tire to maintain it without damage . 


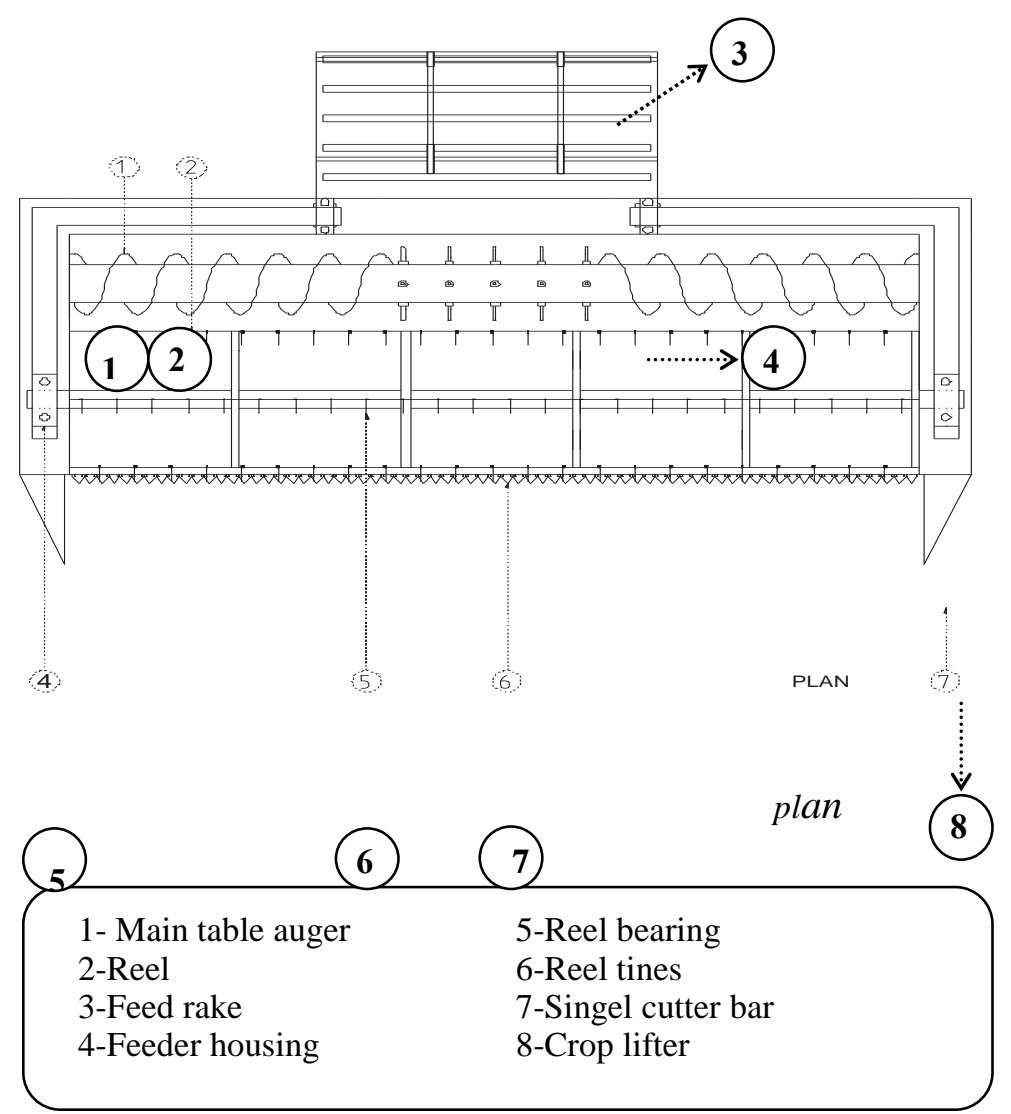

Fig.1. Plan projection for used combine header before modification. 

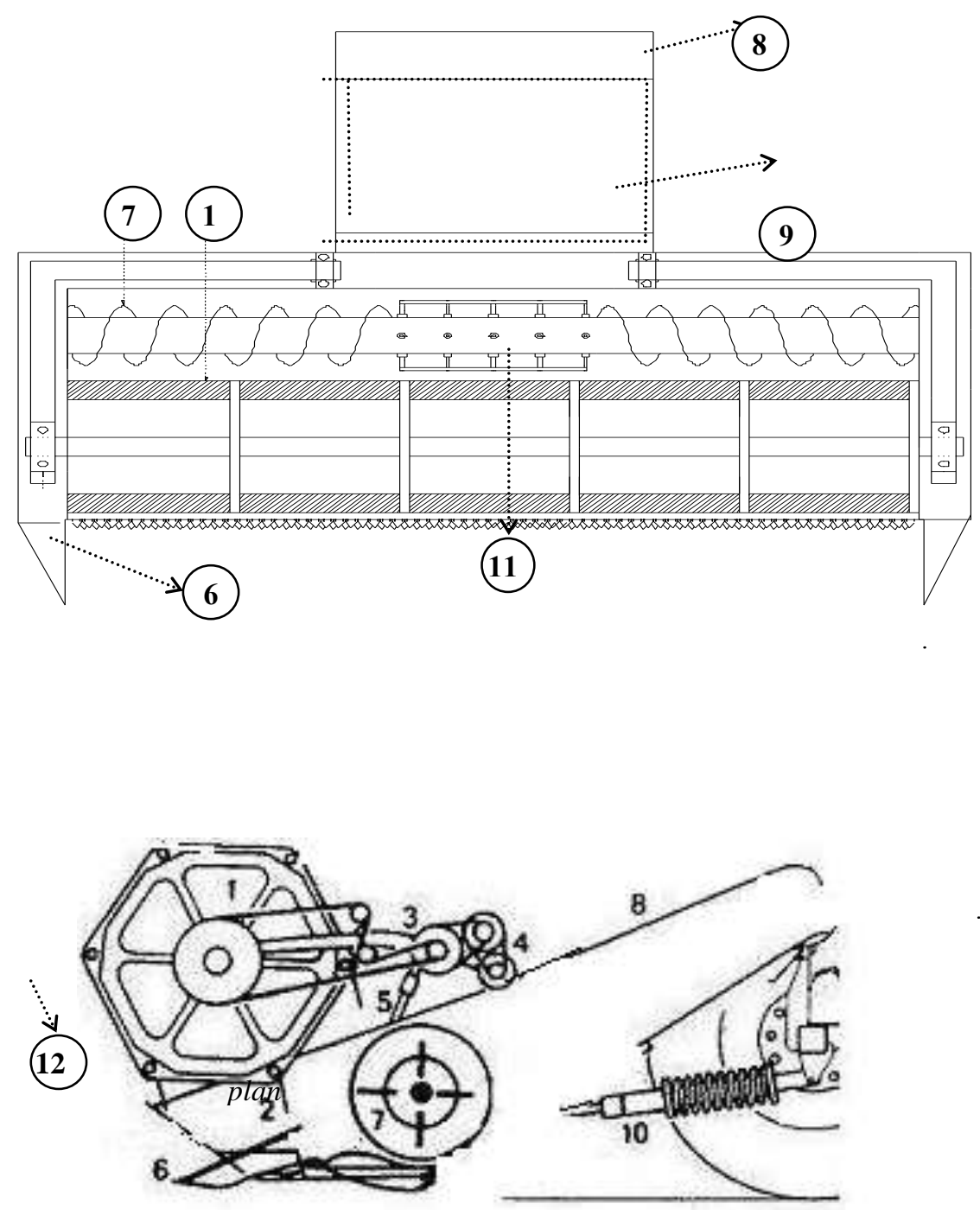

Side view

Fig. 2. Plan and side view projections in the used combine header after modification.

\section{1- Reel}

3-Reel intermediate drive

5-Reel cylinder

7-main feeding auger

9- Cutting yield output opening
2-Reel beams

4-Reel variable speed drive

6- Crop lifter

8- Feeder housing

10- Cutter bar cylinder 


\section{Investigated variables}

1- Forward speed: four forward speeds of $3.20,3.45,3.78$ and $4.32 \mathrm{~km} / \mathrm{h}$, were used in this study.

2- Cutting height : four cutting height were used as follows: 3, 5, 8 and $10 \mathrm{~cm}$.

3- Cutter bar speed: three cutter bar speeds was used as follows:2.28, 3.18 and $3.78 \mathrm{~m} / \mathrm{s}$.

\section{Measurements:}

1- Effective field capacity and Field efficiency : Its were determined under different treatments.

2-Cutting efficiency, \%: The ratio between cutting and uncutting plants in experimental plot (particular area equal $40 \mathrm{~m}^{2}$ ).

$$
\text { Cutting efficiency } \quad=\frac{\mathrm{C} 1}{\mathrm{C} 1+\mathrm{C} 2} \times 100 \quad, \% \ldots \ldots . .1
$$

\section{Where:}
$\mathrm{C} 1$ = Weight of cutting sticks by machine at experimental plot, $\mathrm{Kg}$.
$\mathrm{C} 2=$ Weight of uncutting sticks at experimental plot, $\mathrm{Kg}$.

3- Total losses, \%: It was determined by collecting all stacks which fall down on the field.

Total losses $\quad=\frac{\mathrm{C} 2}{\mathrm{C} 1+\mathrm{C} 2} \times 100 \quad, \% \ldots \ldots . .2$

4- Machine productivity: The machine productivity was determined by weighting the reaping sticks by machine, according to the following equation:

Productivity $\quad=\frac{\mathrm{C} 1 \times 4200}{\mathrm{~A} \times 1000}$, ton/fed $\ldots . . . . .3$

\section{Where:}

A $=$ Total area for harvesting experimental plot, $\mathrm{m}^{2}$.

5- Energy consumed: Energy consumed can be calculated by using the following formula (Imbabi, 1997):

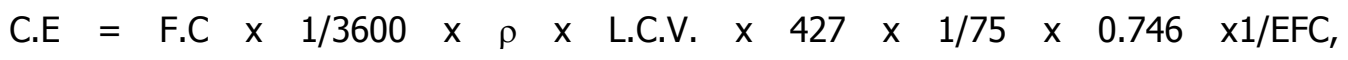
kW.h/fed. .4 


\section{Where:}

C.E = Energy consumed, kW.h/fed,

F.C = the fuel consumption, $\mathrm{l} / \mathrm{h}$,

$\rho=$ Density of the fuel, $\mathrm{kg} / \mathrm{l}$ (for solar fuel is $1000 \mathrm{kcal} / \mathrm{kg}$ ),

L.C.V = Lower calorific value of fuel (for solar fuel is $1000 \mathrm{kcal} / \mathrm{kg}$ ),

$427=$ Constant (thermal- mechanical equivalent, $\mathrm{w} / \mathrm{kcal}$.), and

$\mathrm{EFC}=$ Effective field capacity, fed/h.

6- Operating cost: The total cost need for operation was estimated by the following formula (Awady, 1982):

$$
\text { Operating cost }=\frac{\text { Machine cost, L.E/h }}{\text { Effective field capacity, fed/h }}, \text { L.E/fed.....5 }
$$

Where, machine cost was determined by the following formula (Awady, 1978)

$C=p / h(1 / a+i / 2+t+r)+(0.9$ w.s.f $)+m / 144$.. 6

\section{Where:}

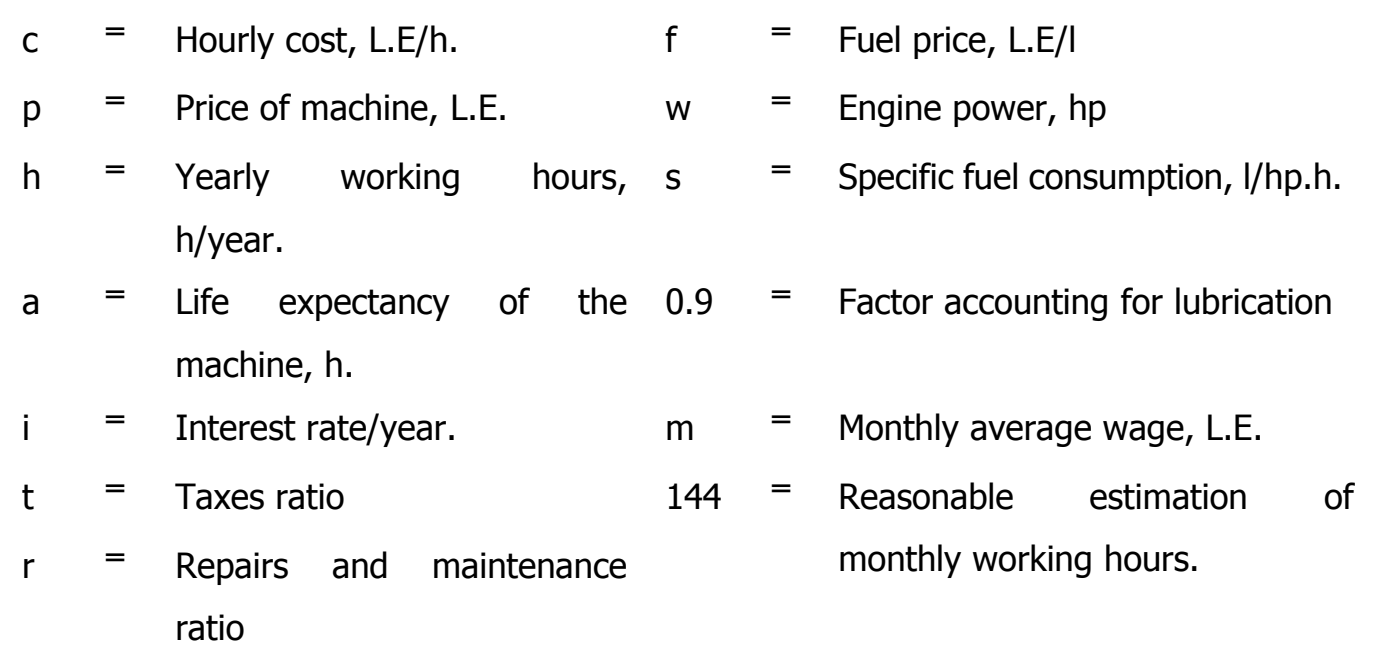

\section{7- Harvesting criterion function cost, L.E/h:}

- Harvesting criterion cost, L.E. / fed = operating cost per fed + total damaged and losses cost per fed. 


\section{RESULTS AND DISCUSSION}

\section{1-Effictive Field Capacity and Field Efficiency}

The obtained results in Fig 2 illustrate the effect of forward speed, cutting height and cutter bar speed on effective field capacity, where, by increasing forward speed from 3.2 to $4.32 \mathrm{Km} / \mathrm{h}$ with constancy cutting height of $3 \mathrm{~cm}$ and cutter bar speed of 2.28 $\mathrm{m} / \mathrm{s}$, the effective field capacity increased from 1.24 to $3.06 \mathrm{Fed} / \mathrm{h}(+146.8)$. while by increasing cutting height from 3 to $10 \mathrm{~cm}$ with constancy forward speed of $3.2 \mathrm{Km} / \mathrm{h}$ and cutter bar of $2.28 \mathrm{~m} / \mathrm{s}$, it increase from 1.24 to $1.5 \mathrm{Fed} / \mathrm{h}(+20.9)$. Also, by increasing cutter bar speed from 2.28 to 3.78 with constancy forward speed of 3.2 $\mathrm{Km} / \mathrm{h}$ and cutting height of $3 \mathrm{~cm}$, it increase from 1.24 to $1.35 \mathrm{Fed} / \mathrm{h}(+8.87)$. On the other hand, field efficiency as shown in Fig 3 was increasing with increase of cutting height and cutter bar speed while, it was decreased with increase of forward speed, Minimum value of field efficiency was $62 \%$ recorded with forward speed of 4.32 $\mathrm{km} / \mathrm{h}$, cutting height of $3 \mathrm{~cm}$ and cutter bar speed of $2.28 \%$. While, maximum value of field efficiency was $90 \%$ recorded with forward speed of $3.2 \mathrm{~km} / \mathrm{h}$, cutting height of $10 \mathrm{~cm}$ and cutter bar speed of $3.78 \%$.As it decrease the forward speed, speed of reel or speed of knife cut the crop increasing rate of entry of the machine becoming more and more actual capacity and field efficiency.

\section{2- Cutting Efficiency}

Data in Fig 4 shows the effect of forward speed, cutting height and cutter bar speed on cutting efficiency. Considering, increasing forward speed from 3.2 to $4.32 \mathrm{Km} / \mathrm{h}$ with constancy cutting height of $3 \mathrm{~cm}$ and cutter bar speed of $2.28 \mathrm{~m} / \mathrm{s}$, cutting efficiency was decreased from 98.1 to $95.4 \%(-2.75)$. While, increasing cutting height from 3 to $10 \mathrm{~cm}$ at constancy forward speed of 3.20 and cutter bar speed of $2.28 \mathrm{~m} / \mathrm{s}$, cutting efficiency was decreased from 98.1 to $97.3 \%$ (-0.82). Also, increasing cutter bar speed from 2.28 to $3.78 \mathrm{~m} / \mathrm{s}$ at constancy forward speed of $3.20 \mathrm{Km} / \mathrm{h}$ and cutting height of $3 \mathrm{~cm}$, cutting efficiency was increased from 98.1 to $98.6 \%(+0.51)$. Where, increasing of forward speed, increase the front directing of crop in to direction of knife cut, leading to overload them reduced, cutting efficiency. While increasing the speed of knife cutter bar pay increase crop into which reduces the header load on the knife cutter bar will become more efficient. 


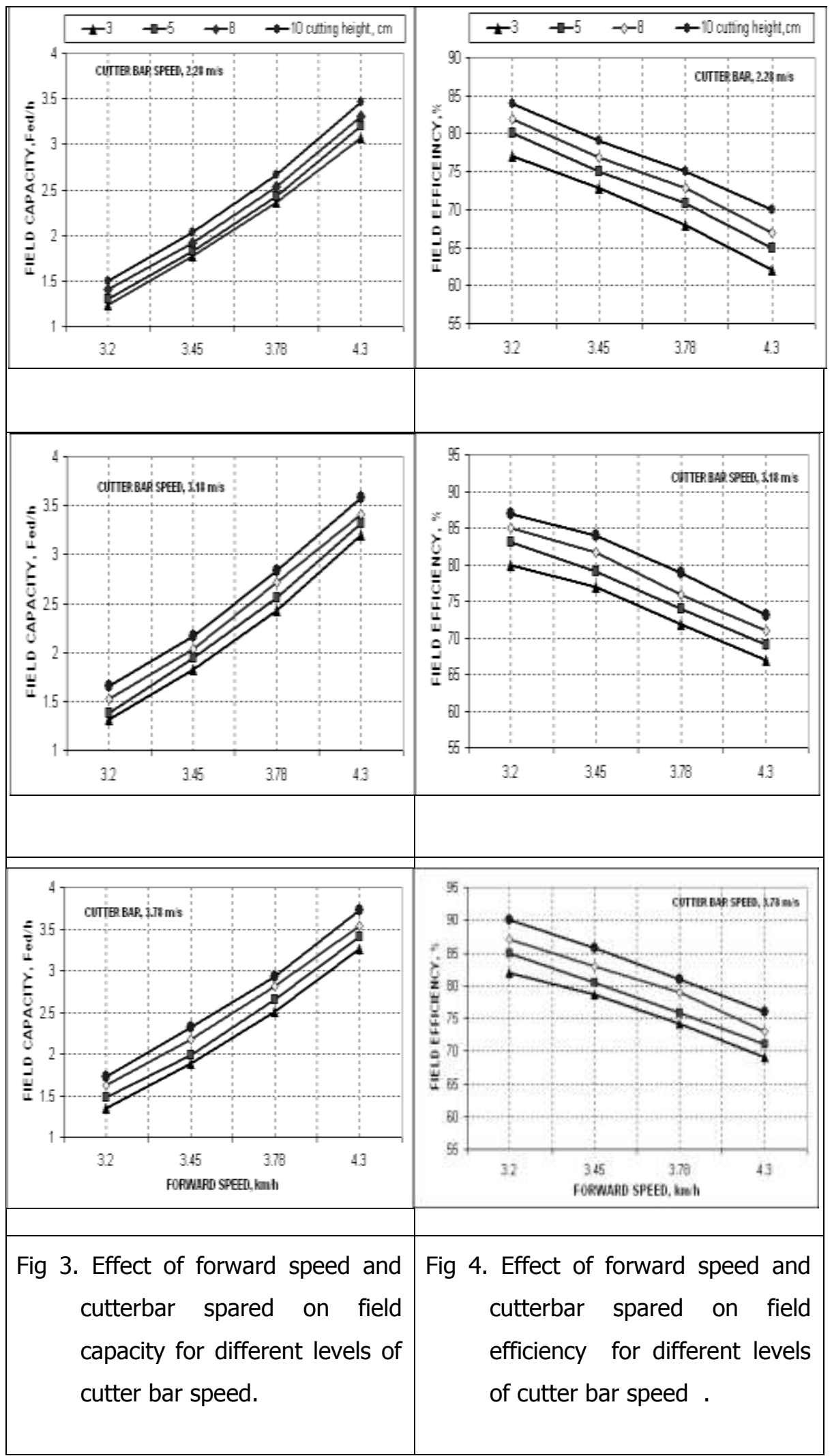




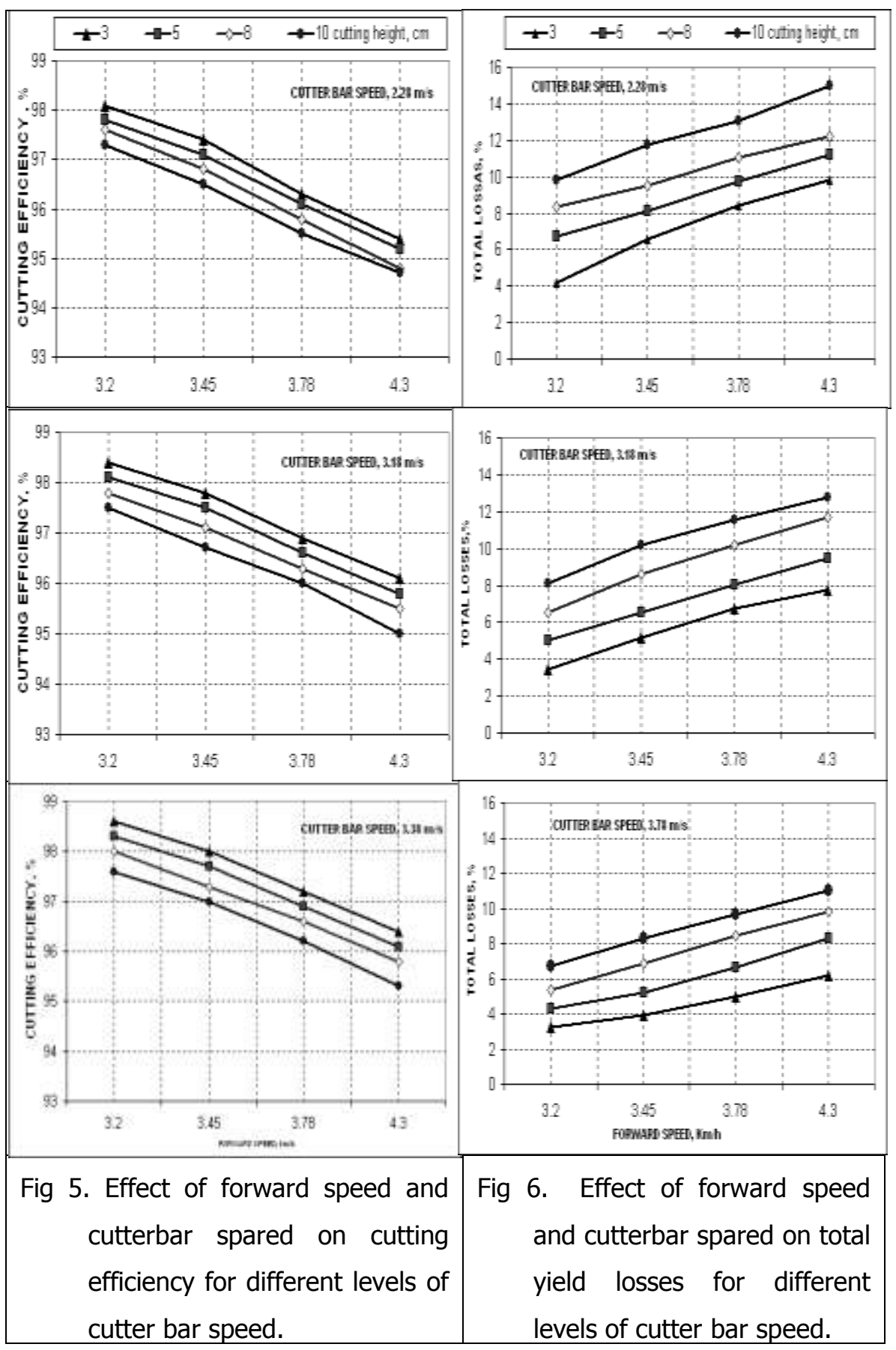

\section{3- Total Losses}

The obtained results showed in Fig 5 indicated that increasing forward speed from 3.2 to $4.32 \mathrm{~km} / \mathrm{h}$, at constancy cutting height of $3 \mathrm{~cm}$ and cutter bar speed of $2.28 \mathrm{~m} / \mathrm{s}$ total losses was increased from 4.41 to $9.83 \%(+122.9)$. While, at increasing cutting height from 3 to $10 \mathrm{~cm}$ at constant forward speed of $3.2 \mathrm{~km} / \mathrm{h}$. and cutter bar speed of $2.38 \mathrm{~m} / \mathrm{s}$, total losses was increased from 4.14 to $9.83 \%(130.92)$. Also, at 
increasing cutter bar speed from 2.26 to $3.78 \mathrm{~m} / \mathrm{s}$ at constant forward speed of 3.20 $\mathrm{km} / \mathrm{h}$ and cutting height of $3 \mathrm{~cm}$, total losses was decreased from 4.14 to $3.28 \%$ (20.77 ). As it increase forward speed of the combine was getting the chance fall of sticks broken on the ground and outside the assembly crop, which is an increase in the percentage of loss and also less than control in reducing the level of cutting, which leads to the left part is greater than the lower part of the plant in the ground, causing an increase the proportion of loss of the crop.

\section{4-Productivity}

Fig 6 shows the effect of forward speed, cutting height and cutter bar speed on combine harvester productivity, it is clear that, productivity was increased with increasing all of forward speed and cutter bar speed while, it was decreased with increase of cutting height. Where the increase rate of forward speed and cutter bar speed of the combine increased rate of entry of the crop, while increasing of cutting height decreased feed rate entry crop to machine. Whereas, increasing forward speed from 3.2 to $4.32 \mathrm{~km} / \mathrm{h}$ at cutting height of $3 \mathrm{~cm}$ and cutter bar speed of $2.28 \mathrm{~m} / \mathrm{s}$, productivity increased from 4.5 to 9.83 ton/h (+118.44). Also, increasing cutter bar speed from 2.28 to $3.78 \mathrm{~m} / \mathrm{s}$, at forward speed of $3.2 \mathrm{~km} / \mathrm{h}$ and cutting height of 3 $\mathrm{cm}$, productivity increased from 4.5 to 5.19 ton/h $(+15.33)$. Meanwhile, Increasing cutting height from 3 to $10 \mathrm{~cm}$ at forward speed of $3.2 \mathrm{~km} / \mathrm{h}$ and cutter bar speed of $2.28 \mathrm{~m} / \mathrm{s}$, productivity decreased from 4.5 to 3.72 ton/h (-17.33). maximum value of productivity was $10.89 \mathrm{ton} / \mathrm{h}$ recorded with forward speed of $4.32 \mathrm{~km} / \mathrm{h}$, cutting height of $3 \mathrm{~cm}$ and cutter bar speed of $3.78 \mathrm{~m} / \mathrm{s}$. 


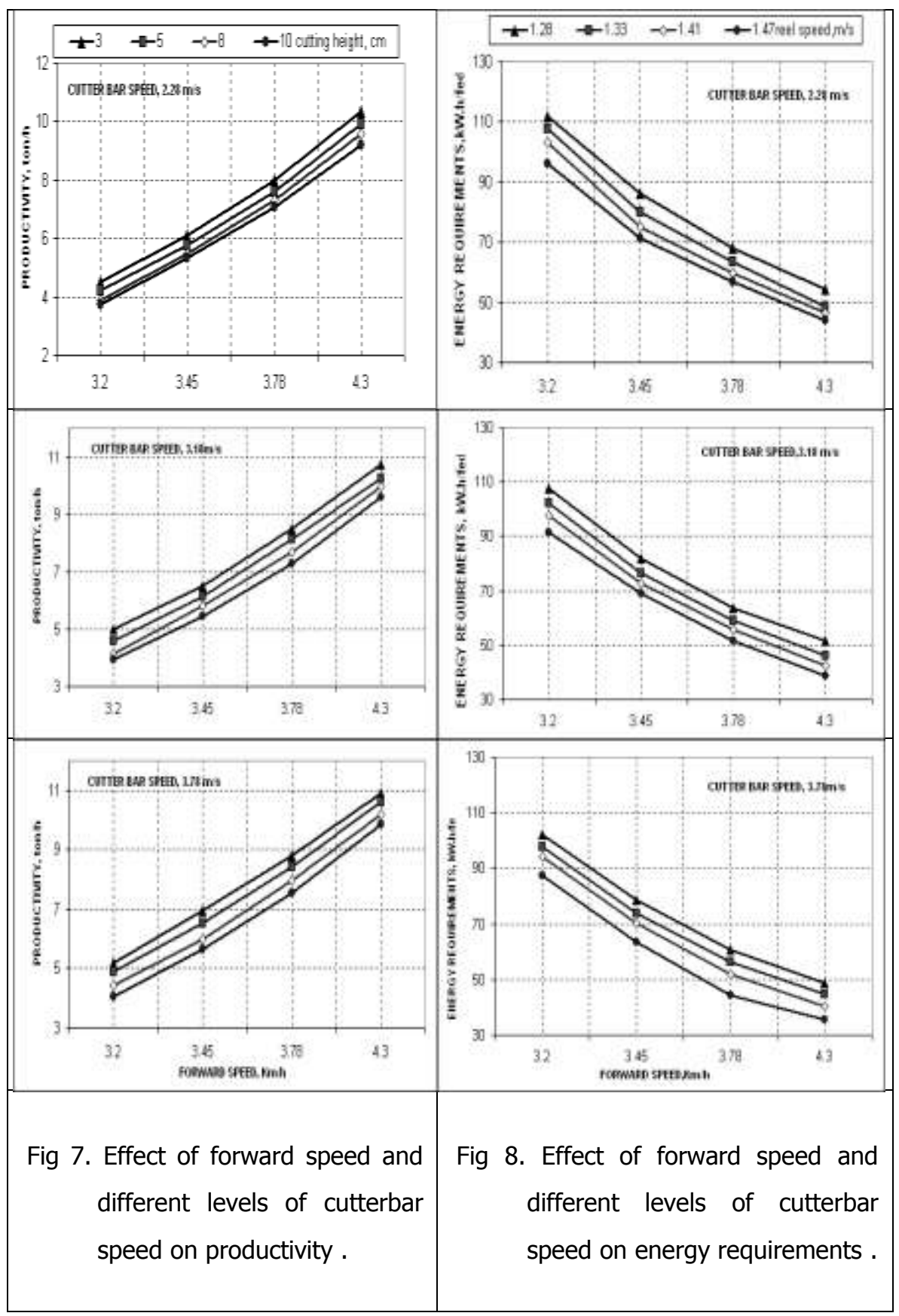




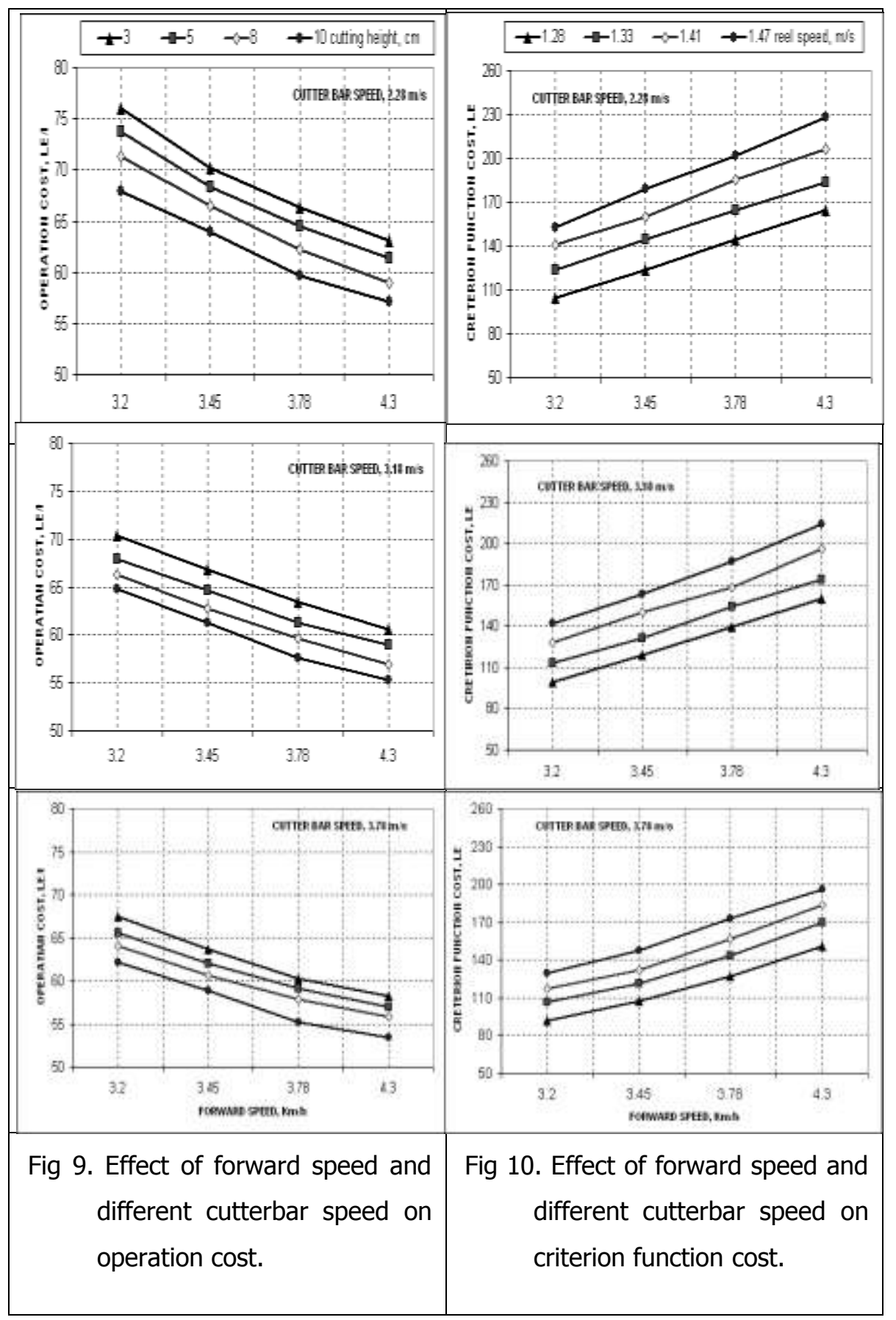

\section{5- Energy Requirements}

Data in Fig 7 shows that the energy requirements decreased with increasing either forward speed or cutting height and with increasing cutter bar speed. Moreover, the maximum value of energy requirements was $111.78 \mathrm{~kW} . \mathrm{h} /$ fed recorded with forward speed of $3.2 \mathrm{~km} / \mathrm{h}$, cutting height of $3 \mathrm{~cm}$ and cutter bar speed of $2.28 \mathrm{~m} / \mathrm{s}$. Meanwhile, the minimum amount of energy requirements was $35.39 \mathrm{~kW} . \mathrm{h} / \mathrm{fed}$ recorded with forward speed of $4.32 \mathrm{~km} / \mathrm{h}$, cutting height of $10 \mathrm{~cm}$ and cutter bar 
speed of $3.78 \mathrm{~m} / \mathrm{s}$. This may be due to increasing both forward and cutting height, lead to increase the feeding rate of the machine, where, Increase as the speed increases achievement and increase field capacity, decreases the rate required energy per feddan.

\section{6 - Operation and Criterion Function Cost}

Results in Fig. 8 illustrate that, operation cost was decreased with increasing of combine forward speed, cutting height and cutter bar speed. whereas, increasing forward speed from 3.2 to $4.32 \mathrm{~km} / \mathrm{h}$, at cutting height of $3 \mathrm{~cm}$ and cutter bar speed of $2.28 \mathrm{~m} / \mathrm{s}$, operation cost decreased from 76.0 to $63.1 \mathrm{LE} / \mathrm{fed}(-16.3 \%)$. Increasing cutting height from 3 to $10 \mathrm{~cm}$ at forward speed of $3.2 \mathrm{~km} / \mathrm{h}$, and cutter bar speed of $2.28 \mathrm{~m} / \mathrm{s}$, operation cost decreased from 76.0 to $67.9 \mathrm{LE} / \mathrm{fed}(+10.6 \%)$. also, the increase of cutter bar speed from 2.28 to $3.78 \mathrm{~m} / \mathrm{s}$, with forward speed of $3.2 \mathrm{~km} / \mathrm{h}$ and cutting height of $3 \mathrm{~cm}$, operation cost decreased from 76.0 to $67.5 \mathrm{LE} / \mathrm{fed}$ ($11.18 \%$ ). From the above it is clear that, forward speed has been more influential factor on operation costs. On the other hand, Fig. 9 illustrates the effect of forward speed and cutting height and cutter bar speed on criterion function cost, where, it was increased by increasing forward speed and cutting height while, it was decreased with increasing cutter bar speed. Whereas, it was increased from 104.2 to 164.7 LE/fed ( $+58.06 \%$ ) by increasing forward speed from 3.2 to $4.32 \mathrm{~km} / \mathrm{h}$ with cutting height of $3 \mathrm{~cm}$ and cutter bar speed of $2.28 \mathrm{~m} / \mathrm{s}$. Also, at forward speed of $3.2 \mathrm{~km} / \mathrm{h}$ and cutter bar speed of $2.28 \mathrm{~m} / \mathrm{s}$, by increasing cutting height from 3 to $10 \mathrm{~cm}$, criterion function cost increased from 104.2 to $153.14 \mathrm{LE} / \mathrm{fed}(+46.96 \%)$. While, at forward speed of $3.2 \mathrm{~km} / \mathrm{h}$ and cutting height of $3 \mathrm{~cm}$ increasing cutter bar speed from 2.28 to $3.78 \mathrm{~m} / \mathrm{s}$ criterion function cost decreased from 104.2 to $91.54 \mathrm{LE} / \mathrm{fed}$ ($12.15 \%$ ). From the above it is clear that the combine forward speeds were more influential factor on criterion function cost as it was the most influential factor on the rate of loss after the impact of any of reel speed and cutter bar speed. Minimum value of operation cost was $53.4 \mathrm{LE} /$ fed recorded with forward speed of $4.32 \mathrm{~km} / \mathrm{h}$, cutting height of $10 \mathrm{~cm}$ and cutter bar speed of $3.78 \mathrm{~m} / \mathrm{s}$ while, minimum value of criterion function cost was $91.54 \mathrm{LE} /$ fed recorded with forward speed of $3.2 \mathrm{~km} / \mathrm{h}$, cutting height of $3 \mathrm{~cm}$ and cutter bar speed of $3.78 \mathrm{~m} / \mathrm{s}$. 


\section{CONCLUSION}

\section{The obtained results can be concluded as follows}

1-At determination both of field capacity and field efficiency for developed header, they were agreed directly with forward speed, reel speed and cutter bar speed. The maximum value of field capacity was $3.72 \mathrm{Fed} / \mathrm{h}$ recorded at using forward speed of $4.32 \mathrm{~km} / \mathrm{h}$, cutting height of $10 \mathrm{~cm}$ and cutter bar speed of $3.78 \mathrm{~m} / \mathrm{s}$ and maximum value for field efficiency was $90 \%$ recorded at using forward speed of $3.2 \mathrm{~km} / \mathrm{h}$, cutting height of $10 \mathrm{~cm}$ and cutter bar speed of $3.78 \mathrm{~m} / \mathrm{s}$.

2- Maximum value of cutting efficiency was $98.6 \%$ recorded with forward speed 3.2 $\mathrm{km} / \mathrm{h}$, cutting height of $3 \mathrm{~cm}$ and cutter bar speed of $3.78 \mathrm{~m} / \mathrm{s}$.

3- Productivity was agreed directly with forward speed and cutter bar speed. While, it was agreed reversely with cutting height, On the other hand, maximum value of productivity was 10.89 ton/h recorded at using forward speed of $4.32 \mathrm{~km} / \mathrm{h}$, cutting height of $3 \mathrm{~cm}$ and cutter bar speed of $3.78 \mathrm{~m} / \mathrm{s}$.

4- Minimum value of total losses was $3.28 \%$ recorded at forward speed of $3.2 \mathrm{~km} / \mathrm{h}$, reel speed of $1.47 \mathrm{~m} / \mathrm{s}$ and cutter bar speed of $3.78 \mathrm{~m} / \mathrm{s}$.

5- Energy requirements was agreed reversely relation with forward speed, cutting height and cutter bar speed.

6- Minimum value of operation cost was $53.4 \mathrm{LE} /$ fed recorded with forward speed of $4.32 \mathrm{~km} / \mathrm{h}$, cutting height of $10 \mathrm{~cm}$ and cutter bar speed of $3.78 \mathrm{~m} / \mathrm{s}$, while, minimum value of criterion function cost was $91.54 \mathrm{LE} /$ fed recorded with forward speed of $3.2 \mathrm{~km} / \mathrm{h}$, cutting height of $3 \mathrm{~cm}$ and cutter bar speed of $3.78 \mathrm{~m} / \mathrm{s}$.

\section{REFERENCES}

1. Awady, M.N. 1978. Engineering of tractors and Agricultural machinery. In Arabic text . Col. of Agric., Ain Shams univ., pp.164-167.

2. Awady, M.N., E.Y. Ghoniem and A.I. Hashish. 1982. Agriculture comparison between wheat combine harvesters under Egyptian conditions. Res. Bul. Ain shams Univ.:13p.

3. Buckmaster, D.R., C. A. Rotz and J. R. Black. 1990. Value of Alfalfa losses on dairy farms .Transactions of the ASAE. 33 (2): 0351-0360.

4. Buckmaster, D. R. and A. J. Heinrichs. 1993. Losses and Quality Changes During Harvest and Storage of Preservative-treated Alfalfa Hay of Varying Moisture Content . Transactions of the ASAE. 36(2): 349-353.

5. Imbabi, A.T. 1997. Performance of three different shapes of rotary cutter during cutting corn- stalks. Misr J. Agric. Eng. , 14(2):229-246. 
6. JoAnn F. S. L., C. S. Craig and A. S. Deborah. 2003. population density and harvest maturity effects on leaf and stem yield in Alfalfa .Agronomy journal, vol. 95, p: 635-641.

7. Koegel, R. G., R. J. Straub and R. P. Walgenbach. 1985. Quantification of Mechanical Losses in Forage Harvesting. Transactions of the ASAE. 28 (4): 10471051.

8. Nazari Galedar, M., A. Tabatabaeefar, A. Jafari and A. Sharifi. 2008 Bending and Shearing Characteristics of Alfalfa Stems". Agricultural Engineering International: the CIGR Ejournal. Manuscript FP 08001 . Vol. X.

9. Rotz. C. A, S. M. Abrams, and R. J. Davis. 1987. Alfalfa drying, loss and quality as influenced by mechanical and chemical conditioning. Transactions of the ASAE. 30:630-641.

10. Rotz, C. A. and S. M. Abrams. 1988. Losses and Quality Changes During Alfalfa Hay Harvest and Storage: Transactions of the ASAE. 31 (2):0350-0355.

11. Shaw, M.D. and L.G. Tabil. 2007. Compression, Relaxation, and Adhesion Properties of Selected Biomass Grinds. Agricultural Engineering International: the CIGR Ejournal. Manuscript FP 07 006. Vol. IX.

12. Sheaffer, C.C., N.P. Martin, J.F.S. Lamb, G.R. Cuomo, J.G. Jewett, and S.R. Quering. 2000. Leaf and stem properties of alfalfa entries. Agronomy journal. 92:733-739.

13. Yiljep, Y. D. and U.S. Mohammed. 2005. Effect of Knife Velocity on Cutting Energy and Efficiency during Impact Cutting of Sorghum Stalk. Agricultural Engineering International :the CIGR Ejournal. Manuscript PM 05 004. Vol. VII. 
تعديل صدر كومباين حصاد محاصيل الحبوب لضم البرسيم الحجازي

عاطف عزت اليماني 1 سمير خضر جنيدى 2

$$
\begin{aligned}
& \text { 1. معهز بحوث الهندسة الزراعية - مركز البحوث الزراعية - مصر . }
\end{aligned}
$$

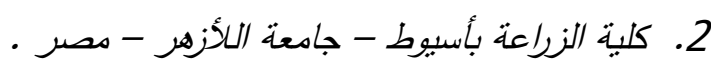

بعتبر البرسيم الحجازي أكثر محاصيل الأعلاف المنزرعة أهمية عالمباً كما أنه يوصف بأنه

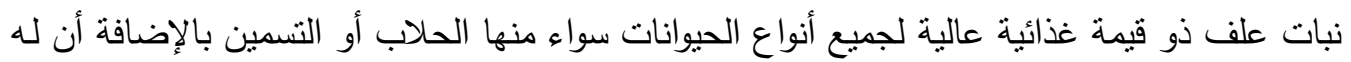

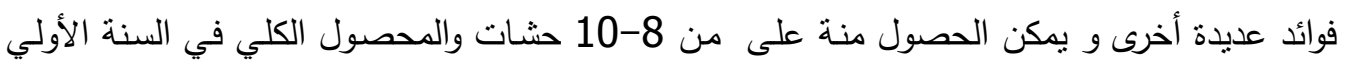

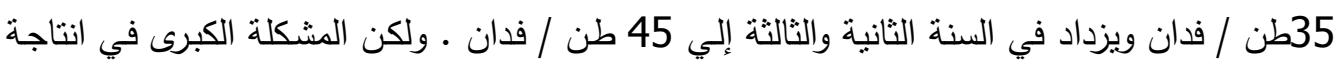

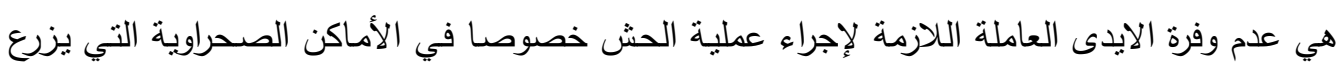

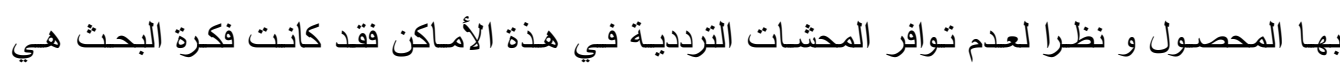

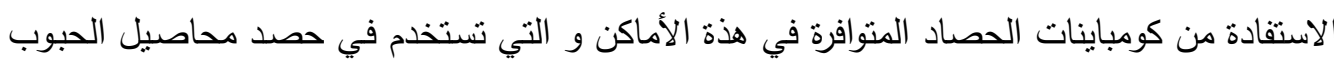

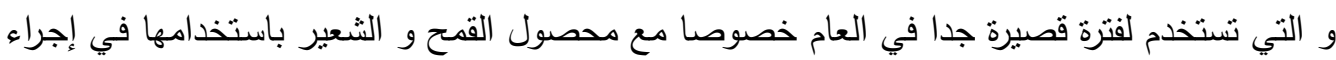
عملية حش البرسيم الحجازي و ذلك بإجراء تعديل في صدر الكومباين ليناسب حش البرسيم العبام العازي.

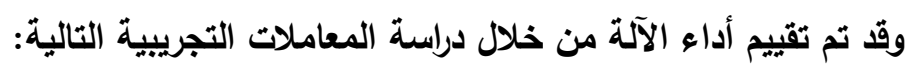

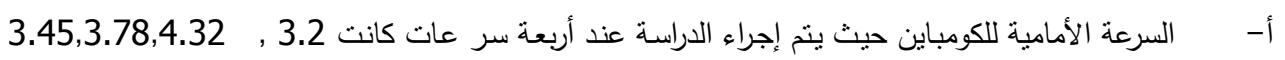
كم/س.

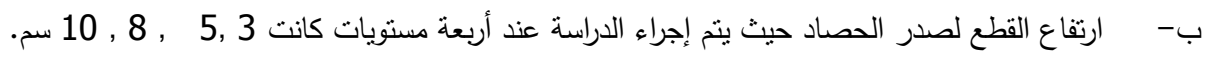

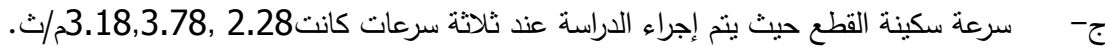

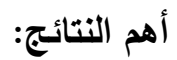

1- السعة الحقلية كانت تزداد بزيادة كل من سرعة التقدم للكومباين و ارتفاع القطع و سرعة سكينة

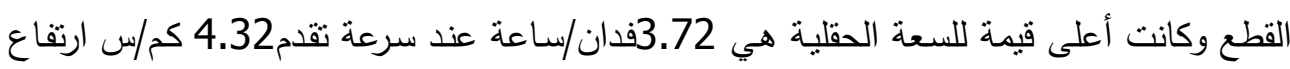

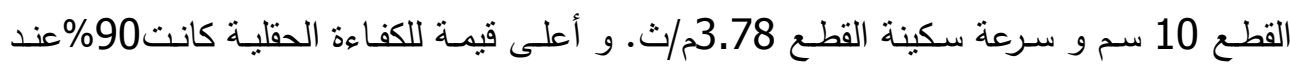
سرعة تقدم3.2 كم/س وارتفاع القطع 10 سم و سرعة سكينة القطع 3.78 3.78/ثاث.

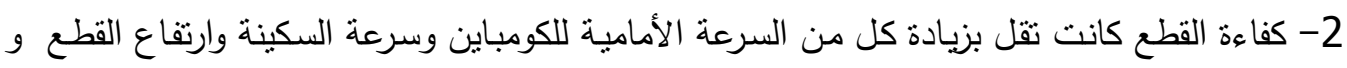

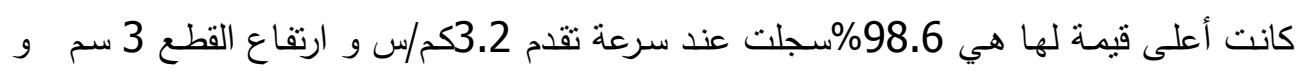

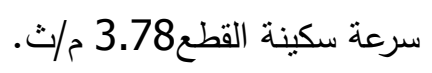
3- الإنتاجية كانت تزداد بزيادة كل من سرعة النقام للكومباين و ارتفاع القطع و سرعة سكينة القطع و

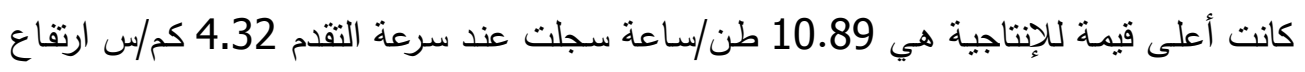

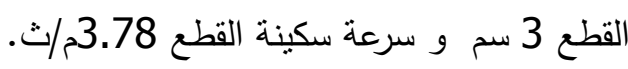


4- نسبة الفقد كانت نزداد بزيادة السرعة الأمامية و ارتفاع القطع بينما كانت نقل بزيادة سرعة السكينة

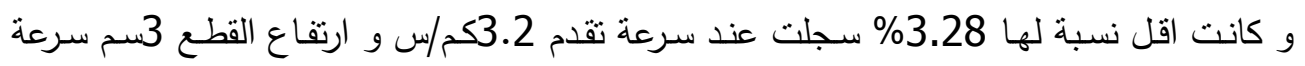
سكينة القطع 3.78م/ث.

5- الطاقة اللازمة للفدان كانت نقل بزيادة كل من السرعة الأمامية و ارتقاع القطع و سرعة السكينة و

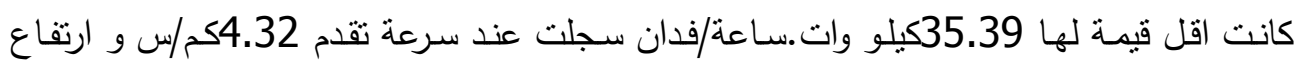
6 القطع 10 سم و سرعة سكينة 3.78م/ثلث. 6- اقل قيمة لتكاليف التشغيل كانت 53.4جنية/فدان سجلت عند سرعة تقدم

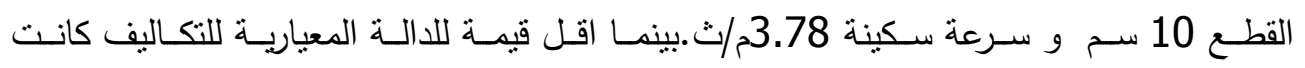
91.54جنيها /فدان سجلت عند سرعة تقدم 3.2كم/س و ارتفاع القطع 3 سم و سرعة سكينة القطع 3.78م/ث. 